\title{
DIE GEREFORMEERDE KERKVERBAND AS SOCIETAS VAN PLAASLIKE GEMEENTES
}

Prof. dr. L. Roeleveld

\section{WAT IS 'N SOCIETAS ?}

Gijsbert Voet noem die samewerking tussen plaaslike gemeentes correspondentia, wat algemeen - maar onnoukeurig en dubbelsinnig - gewoonlik vertaal word deur ,kerkverband”. Daardie verband tipeer hy op baie maniere. Een daarvan is die benaming mutua societas ${ }^{1}$, terwyl hy die gemeentes as socii ${ }^{2}$ aandui.

Wat bedoel Voet met hierdie uitdrukkings? Die agtergrond van die gemene reg van sy tyd kan moontlik opheldering gee. Die Latynse woord societas kan beteken bondgenootskap, deelneming, gemeenskap, geselskap, handelmaatskappy, vennootskap, verbond. Socius is bondgenoot, metgesel, deelgenoot, kompanjon, lid van 'n vennootskap ${ }^{3}$.

Mutua societas is wederkerige vennootskap. Dit dui op die wederkerige of onderlinge verhouding van die vennote jeens mekaar.

Die Romeinse reg betrek vennootskap op alle goedere 4. Dit sluit broederskap in ${ }^{5}$. 'n Vennootskap kan ook beoog word vir een bepaalde transaksie, byvoorbeeld koophandel. Dit kan aangegaan word vir onbepaalde tyd (in perpetuum), d.w.s. solank al die vennote in lewe is, of vir ' $n$ bepaalde tyd of onder ' $n$ bepaalde voorwaarde ${ }^{\circ}$.

Die Romeins-Hollandse reg het 'n ruimer begrip van vennootskap. Hugo de Groot stel: „Maetschap, ofte Vennoodschap is een overkominge van twee, ofte meerder luyden, om door gemeenschap van goederen ofte dienst gemeene baet te trekken '..... ende kan in deze gemeenschap komen al wat eerlyk is, maar niets oneerlyke" " .

Hierdie begrip veronderstel nie net die inbring van liggaamlike sake deur die vennote in 'n gemeenskap nie. Dit kan ook iets anders wees, te wete diens of arbeid. 'n Vennootskap hoef dus glad nie 'n stoflike winsmotief te hê nie ${ }^{\theta}$. Dit word wel die geval as vennote met die vennootskap 'n gesamentlike uitoefening van 'n handelsbedryf beoog, maar dit is nie wesenlik vir 'n vennootskap nie. Die essensie van 'n vennoootskap is dus nie winsdoel nie, maar die samewerking deur en tussen die vennote.

Die Nederlandse regsontwikkeling bou duidelik op die RomeinsHollandse reg voort. Art. 1655 Burgerlijk Wetboek (van 1838 bepaal: „Maatschap is eene overeenkomst, waarbij twee of meerdere personen zich verbinden om iets in gemeenschap te brengen, met het oogmerk om het daaruit ontstaande voordeel met elkander te deelen." Jolles ${ }^{10}$ stel: :,,delen in art $1655 \mathrm{BW}$ is niet verdelen, doch deel hebben in; niet diviser doch partager."

Die hoogste Nederlandse geregshof het hom hieroor ook baie duidelik uitgedruk ${ }^{11}$ : „Voor het bestaan van een vennootschap is een gemeenschappelijk vermogen niet wezenlijk en evenmin dat, indien zodanig vermogen aanwezig is, ieder der vennoten daarin 
zakelijk of althans voor wat hun onderlinge verhouding betreft madegerechtigd is. Onder het in gemeenschap brengen in de zin der wet is slechts te verstaan het geven van een bijdrage ter bereiking van het vennootschappelijk doel, zonder dat vereist is, dat deze bijdrage bestaat uit enig vermogensbestanddeel, noch dat, indien zij daaruit bestaat, dit vermogensbestanddeel gemeenschappelijk eigendom wordt."

In die Nederlandse, aan die Romeinse reg ontleende stelsel, is die begrip vereniging ruimer dan die van maatskap. By 'n vereniging is die inbringplig van die lede nie essensieel nie.

As 'n mens hierdie reëls op die kerkverband as maatskap (=vennootskap - geen regspersoon nie) toepas, bestaan die verpligting tot inbring van arbeid en diens in adviese en in die deel$n^{n}$ ming aan die besluitvorming oor sake ten behoewe van al die gemeentes wat daardie organisasie vorm. As hulpbehoewende gemeentes vrygestel word van betaling van hul finansiële bydrae in die kerkverband, gaan die karakter van maatskap dus nie verlore nie.

Die verskillende benaming van maatskap en vennootskap vir dieselfde saak het in die Afrikaanse regstaal verlore gegaan. Daarin is die woord maatskappy ook gereserveer vir 'n vereniging-regspersoon. Oorspronklik was dit nie die geval nie. Boey ${ }^{12}$ vermeld dat die woord vennoot (in ou spellings veneut, veinoot) van die ou Dene afkomstig is en maat of maatskappy beteken. Koenen ${ }^{13}$ noem 'n maat 'n makker, spysgenoot, gezel en vermeld in dié verband die uitdrukking van Jan Rap en sy maats.

Die enigs moontlike gevolgtrekking hieruit is dat die gebruik deur Voetius van die benamings socictas en socii en deur Spoelstra van ,vennootskap' met betrekking tot die gereformeerde kerkverband reg is. Die essensiële begrip samewerking word pragtig in die term correspondentia... uitgedruk. Correspondere beteken: aan mekaar iets belowe of advies gee of vir mekaar instaan. Die respona jurisprudentium was die regsgeleerde adviese, een van die bronne van die Romeinse reg ${ }^{14}$. Die Nederlandse regsgeleerdes het dieselfde gedoen in hul Hollandse Consultatiën ${ }^{15}$. Dit is nog altyd 'n kenbron van die gemene Suid-Afrikaanse reg. Teen daardie agtergrond kry die begrip correspondentia, „kerkverband”, sin en betekenis: die plaaslike gemeentes gee in 'n vennootskaplike verband mekaar advies, hulp en bystand, moreel en finansiëel.

So 'n vennootskaplike verhouding kan ook 'n naam hê. Net soos 'n handelsvennootskap sonder om 'n regspersoon te wees 'n „firma" (d.i. die Italiaanse woord vir naam) kan hê, is dit met 'n verband van kerke (kerkverband) die geval.

Die Gereformeerde Kerk in Suid-Afrika is die naam van die verband van gereformeerde gemeentes alhier. Die enkelvoud doen niks af aan die gemis van regspersoonlikheid nie, wanneer hierdie naam die karakter van die universele kerk as 'n eenheid tot uitdrukking wil bring nie ${ }^{16}$. Voornoemde maatskapsverhouding het niks te doen met die regsverhoudings binne die plaaslike gemeente nie ${ }^{17}$. 


\section{'N SOCIETAS IS IN DIE ALGEMEEN GEEN REGSPERSOON NIE}

'n Vennootskap is 'n samevoeging van persone. Nie elke samevoeging van persone is 'n regspersoon nie, selfs nie as hul 'n eenheid vorm nie. 'n Getroude man en sy vrou word een vlees, die innigste denkbare eenheid onder mense op aarde. Die huwelik vir die duur van hul lewe is tog nie 'n regspersoon nie. Dieselfde geld vir die gesinseenheid van ouers en kinders. Dieselfde geld vir vennote as amici en fratres.

In die regsbronne van voor 1800 is die term regspersoon nie te vinde nie. Die benaming het hoofsaaklik sedert Von Savigny in die hedendaagse regspraktyk ingeburger. Die saak self is egter reeds baie oud. Die Romeinse reg voor die Christelike keisertyd noem net korporasies regspersone. Die reg van die keisertyd bepaal dat wat aan geen natuurlike persone behoort nie, aan die universitas, dit is aan die geheel, toekom. Nie elke eenheidsorganisasie is egter weer 'n regspersoon nie ${ }^{18}$.

'n Vennootskap kan wel deur besondere bepalings tot 'n regspersoon uitgroei. So is die Verenigde Oos-Indiese Kompanie in 1602 opgerig op die grondslag van die vennootskapsverhouding van die deelnemende reders. Die bedoeling van die oprigtingsooreenkoms was om 'n maatskappy-regspersoon te vorm. Dit het die eerste ,moderne' maatskappy in die Romeins-Hollandse regstoepassing geword ${ }^{19}$.

Die gedeeltelike gesag wat die nasionale Nederlandse state in 1579 volgens die Unieverdrag van Utrecht oorgedra het, het dit tot 'n publiek-regtelike regspersoon gemaak, wat in 1581 republikeinse status met eie oorspronklike bevoegdhede verkry het ${ }^{20}$. Die Nederlandse gereformeerde vennoootskaplike kerkverband is deur die Koninklike reglementering in 1816 tot 'n landelike kerkgenootskap as regspersoon omskep, waarvan die plaaslike gemeentes onderafdeling gaan vorm het. Die meerdere vergaderinge het bestuurskolleges geword, met gesag elkeen na sy eie aard en bepalings. Dit het daarop neergekom dat die sinodes die hoëre en die kerkrade die laere kolleges was. Hierdie vorm van hiërargie word aangedui met die term kollegialisme.

Deurdat hierdie voorbeeld in 1824 aan die Kaap gevolg is, is die Kaaplandse kerk uit Nederland erfelik belas. Die resultaat daarvan is dat die Nederduitse Gereformeerde Kerk en, in nog sterker mate die Nederduits Hervormde Kerk van Afrika, uit provinsiale regspersone bestaan, wat tesame 'n landelike genootskaplike regspersoon vorm.

Die Afskeiding van 1834 en die Doleansie van 1886 was 'n hewige reaksie teen hierdie hiërargie in Nederland, wat in die eerste decennia selfs met onwettige staatsmag afgedwing is. Die beginsel van 'n vrye kerk in 'n vrye staat is duidelik vasgelê in die Grondwet van 1848. Daarna, in 1853, het die ,Wet tot regeling van het toezicht op de onderscheidene kerkgenootschappen" aan die kerke net voorgeskryf dat ,de bepalingen van inrichting en het bestuur door de bestuurders of hoofden der kerkgenootschappen aan de regering meegedeeld moeten worden". Hoe het die onderskeie kerke hierop gereageer? 
Die Roomse Kerk en die Nederlands Hervormde Kerk het hul as landelike regspersone laat inskryf op die lys van die Departement van Justisie. Die Gereformeerde Kerke het dit egter nie gedoen nie. Aangesien hul volgens hul eie opvatting, wat op die Dordtse Kerkenorde berus, nie as 'n landelike genootskap-regspersoon georganiseer is nie, het hulle die vaste praktyk gevolg dat sinodale deputate die bestaan en verandering in plaaslike gemeentes as ,kerkgenootschappen' in die sin van die wet van 1853 laat registreer. Die pretensie hiervan is duidelik: Tot alle prys moet die indruk voorkom word dat die gereformeerde gemeentes kollegialisties en genootskaplik georganiseer is. Die Reformasie het eerste die stryd teen die hiërargie van Rome aangebind. In 1834 en 1886 is teen die tweede hiërargie van 1816 gereageer ${ }^{21}$. Die Vrygemaaktes het die derde hiërargie van sinodekrasie in 1944 verwerp ${ }^{22}$.

Dieselfde saak het by die herformulering van die Nederlandse burgerlijke reg ter sprake gekom. Die wet bepaal sedert 1976: „Kerkgenootschappen, alsmede hun zelfstandige onderdelen bezitten rechtspersoonlijkheid." Hierdie bepaling, gelees in verband met genoemde wet van 1853 , doen geen geweld aan die vennootskaplike karakter van die gereformeerde kerkverband nie, want hier is die plaaslike gemeentes „genootschappen-rechtspersoon" 2s. Die wet bepaal voorts: „Zij worden geregeerd door hun eigen statuut, voor zover dit niet in strijd is met de wet." In die oorspronklike ontwerp was nie van "statuut", maar van "reglementen" sprake. 'n Vrygemaak-gereformeerde parlementslid het bewerk, dat die histories belaste benaming „reglementen”, wat herinner aan die „Reglementen" van die kollegialistiese genootskapskerk van Willem I in 1816, uit die wetsontwerp verwyder is ${ }^{24}$.

In die algemeen gangbare regskundige spraakgebruik is 'n „vennootskap" dus geen regspersoon nie, maar 'n "genootskap" wel 'n regspersoon. Origens moet in gedagte gehou word: Verba valent usu. Die benaming van 'n regsverhoudingg sê nog niks definitiefs oor sy regskarakter nie. Die naam kan 'n aanwysing gee, maar die begrip moet volgens sy innerlike waarde getoets word ${ }^{25}$. Daarom het ek vroeër ${ }^{26}$ daarop gewys dat ek in die ou regspraktyk onder die benaming societas en "societyt" instellings gevind het wat wel regspersone was. Onder 'n genootskapsooreenkoms word gewoonlik 'n kontrak tussen natuurlike of regspersone verstaan om 'n genootskap as regspersoon sonder winsoogmerk op te rig ${ }^{27}$.

\section{VOETIUS OOR DIE KARAKTER VAN DIE KERKVERBAND}

By Voetius is daar geen enkele aanduiding dat die correspondentia ecclesiarum 'n regspersoon sou wees nie ${ }^{28}$. Die teendeel is die geval. Voetius dui die kerkverband op baie maniere aan soos volg ${ }^{20}$ : (1) correspondentia; (2) conjunctio (verbintenis, verbinding, band, wat hy onderskei in communicatio (die meedele) en combinatio (samevoeging van twee aan twee), (3) unio (eenheid of vereniging), (4) communio (gemeenskap), (5) confoederatio (verbond), (6) collectio plurium membrorum in una congregatione; ista collectio et combinatio plurum Ecclesiarum in unum coetum seu synodum ('n versameling van meer lede in een kudde ${ }^{30}$ en 'n samevoeging 
van meer gemeentes in een samekoms of sinode), (7) consociatio (vereniging, verbinding).

Voetius gee die volgende begripsomskrywing ${ }^{31}$ : Classicalis seu synodalis correspondentia est stata combinatio plurium Ecclesiarum sub certo regimine et correspondentia ad mutuam aedificationem et conservationem (die klassikale of sinodale korrespondensie is ' $n$ vaste samevoeging van meer gemeentes onder ' $n$ bepaalde statuut ${ }^{32}$ en korrespondensie tot wederkerige stigting en bewaring of instandhouding van die gemeentes).

Oor die onderlinge verhouding van gemeentes in die kerkverband stel hy ${ }^{33}$ : Relatum et correlatum sunt Ecclesiae institutae parochiales integrae inter se collaterales et potestate Ecclesiaticae aequales ....e. gr. amici, socii, confoederati, collegae et membra.... collegiorum Politicorum... (die plaaslike geïnstitueerde ${ }^{34}$ gemeentes is onverkort ${ }^{35}$ onderling as verwantes ${ }^{86}$ verbonde en gelyk in kerklike gesag.... soos byvoorbeeld vriende, vennote, bondgenote, kollegas en medeburgers).

Voetius lei uit Handelinge 15 en 2 Kor. 8 af ${ }^{37}$ dat die grondslag van die kerkverband is die consensus mutuus Ecclesiarum ad talem correspondentiam et confoederationem, ex debito mutuae societatis, non ex debito inferioris conditionis ad praestandum obsequium (die wedersydse toestemming, wilsooreenstemming, van die gemeentes tot sodanige korrespondensie en bondgenootskap, uit verpligting van hul wederkerige vennootskap, nie uit verpligting van 'n ondergeskikte posisie om onderdanigheid te bewys nie).

Voetius merk op ${ }^{38}$ dat die noodsaaklikheid van kerkverband nie absoluut is nie ${ }^{30}$ : non ad esse Ecclesiasticum simpliciter, sed tantum ad bene esse (dit behoort nie tot die wese van die kerk nie, maar net tot die welwese).

Oor die gesag van meerdere vergaderings laat hy hom soos volg uit ${ }^{10}$ : As hul besluite contra Scripturam, fundamentales leges Ecclesiasticas (teen die Skrif en fundamentele kerkreg) is.... Ecclesiae particulares decreta eorum non recipiunt, nec executioni mandant; sed in medio relinquunt, aut rescindunt (aanvaar die afsonderlike gemeentes die besluite van hul afgevaardiges nie, nog beveel hul die uitvoering daarvan, maar ignoreer of vernietig hul). Daar moet dan 'n nuwe vergadering kom van afgevaardigdes uit die kerkrade. Die gesag van samekomste wat uit afgevaardigdes bestaan is:

1. non quod ad perpetuam possessionem, sed quod ad exercitium tantum (nie van voortdurend besit nie, maar net van uitoefening daarvan ${ }^{11}$ )

2. et quidem non absoluta sed limitata (en egter nie absoluut nie, maar beperk)

3. non magistralis sed ministerialis (nie heersend nie, maar dienend):

4. non summa, sed inferior.... (nie hoër nie, maar laer)

5. non originalis, sed derivata et delegata (nie oorspronklik nie, maar afgelei en gedelegeer)

6. non tam ex praerogativa jurisdictionis, quam aestimationis et 
reverentia (nie soseer uit 'n prerogatief van regsbevoegdheid nie as uit waardering en agting).

Die gesag van die afgevaardigdes na die meerdere vergaderinge is nie soos die van ons ouers ten opsigte van kinders, here en slawe, base en knegte nie; maar soos van gelykes sonder skending van vryheid en gelykheid; soos dit regtens is tussen broeders, vriende, kollegas, bondgenote, medeburgers. Daar kan geen proprie dictum (eintlike) subordinatio, subjectio, obedientia, imperium.... inter Ecclesias in unam classem aut synodum consociatas (ondergeskiktheid, onderwerping, gehoorsaamheid, mag tussen gemeentes in een klassis of vereniging van sinodes) nie bestaan nie, sed tantum mutua et aequalis dependentia; ad mutua consilia et auxilia praestanda (maar slegs 'n wederkerige en gelyke afhanklikheid om mekaar raad en hulp te gee).

Voetius beskou 'n meerdere vergadering nie as 'n vergadering van meer gemeentes nie ${ }^{42}$, maar van hul afgevaardigdes ${ }^{43}$ : Conventus classicus constat ex delegatis Ecclesiarum parochialium, synodicus vero provincialis ex delegatis classium; synodicus nationalis ex delegatis synodorum Provincialium seu particularium. Dit is dus nie so dat die gemeentes 'n algemene verband daarstel en dat hul daarheen afgevaardigdes stuur nie ${ }^{44}$. Die kerkverband as verbond, d.i. vennootskap van gemeentes is 'n permanente kontraktuele regsband tussen die gemeentes solank die vennootskap bestaan. Dit is inderdaad nie ad hoc, maar voortdurend bedoel. As egter 'n sinode saamkom is dit 'n conventus van afgevaardigdes van vennote, dus ' $n$ eventus (gebeurtenis) wat die verbond in hul vergaderingsgemeenskap beoefen.

Sou die kerkverband 'n genootskap-regspersoon wees, dan was dit anders. In daardie geval vorm die afgevaardigdes as collegium die bestuur van die landelike of provinsiale kerk. Dit is kollegialisties.

Geldenhuys ${ }^{45}$ wys daarop dat Rutgers, Kuyper en Schokking die korporatiewe eenheid ontken van 'n landelike kerk met 'n beroep op Voet P.E. IV, bl. 167. M. Bouwman en hy lees uit dieselfde woorde juis die teendeel. Wie is reg? Die teks lui soos volg:

Vraag: An et quando coetus classici aut synodici sint et dici possint ecclesia, aut acclesia visibiles et particulares?

Antwoord: Ecclesia una in singulari numero proprie dici non possunt; sed tropici, quia respraesentant ecclesias et associantur et agunt in illo coeto quasi ecclesia una....

Ecclesiae unitae seu combinatae (in plurali numero) dicuntur, non primo et immeditate, sed secundo et meditate per delegationem scil: quia sunt aliqui $a b$ ecclesiis dleegati, in quibus et per quos ecclesiae delegantes intelliguntur ibi convenire et agere, et sic actualiter suam correspondentiam exercere. Primo autem et immeditate correspondentia seu unio plurium ecclesiarum et tribuitur ipsis ecclesiis: quae etiam continuo manet, sive synodus habeatur sive non; et actis correspondentia aliquis hic et nunc exerceatur, aut non exerceatur, haut aliter ac foedera, conjugia, ministeria ecclesiastica etc. Hinc patet non introduci a nobis novam et distinctam ecclesiae formam; ob nullam aliam 
rationem, congregationes istae multae, Ecclesiae nomine in singulari numero designantur, nisi quod a pluribus Presbyteris eas pascentibus, majorisque momenti res in Classicali Conventu determinantibus, in communi gubernarentur. Hujusmodi fuit Ecclesia Aphesina Actor 20117 et Hierosolymitana Act 11,22. Ek vertaal en parafareer tegelykertyd:

Vraag: Of en wanneer gesê kan word dat klassikale en sinodale vergaderings (meervoud) een kerk (enkelvoud) of sigbare en afsonderlike kerke (meervoud) is?

Antwoord: In eintlike sin (dit is: in die werklikheid) kan nie gesê word dat hul (slegs) een kerk in die enkelvoud is nie; maar figuurlik gesproke (in beeldspraak) omdat hul (die vergaderinge, nie die gemeentes nie) die gemeentes (meervoud) verteenwoordig en hul hul verenig (socii, dus op voet van gelykheid) en handel in daardie samekoms asof (quasi=soos, nie ,as' nie) hul slegs een kerk is....

Die gemeentes word aangedui as verenig en gekombineer - in die meervoud -, nie ten eerste (oorspronklik) en regstreeks nie, maar in die tweede plek en middellik deur afvaardiging, te wete: omdat sommige persone deur die gemeentes afgevaardig word; die gemeentes word verstaan hier (in meerdere vergadering) by mekaar te kom in en deur hul afgesante, en op hierdie manier metterdaad hul korrespondensie (samewr rking) te bcoefen. Die korrespondensie en vereniging van meer gemeentes word allereers en regstreeks toegereken aan die gemeente self: hierdie (samewerkingsverbond) bestaan voortdurend, ongeag of 'n sinode vergader al dan nie; ook al word soms die korrespondensie slegs af en toe deur dade beoefen, of nie beoefen nie. Dit is niks anders as in geval van (volkeregtelike) verdrae (in welk geval die deelnemende state nie in 'n groter eenheidstaat opgaan nie), verbande tussen persone (soos huwelik wat nie 'n regspersoon is nie), kerkrade (wat ewemin regspersone is) ens. Hierdeur is dit duidelik dat deur ons nie 'n nuwe of aparte vorm van kerk (as regspersoon) ingevoer word nie. Weens geen enkele andere rede word hierdie baie gemeentes met die naam van kerk in die enkelvoud aangedui nie as dat (hierdie gemeentes) gemeenskaplik geregeer word deur meer ouderlinge as hul herders wat in sake van groter belang in die klassikale vergadering besluit. Vgl die gemeentes van Efese (Hand. 20:7) en van Jerusalem (Hand. $11: 22)$.

Ek glo nie dat Voetius in nog duideliker taal kon uitgedruk het dat 'n gereformeerde kerkverband juis nie 'n regspersoon is of kan wees nie ${ }^{48}$.

\section{VERSKIL TUSSEN FRANSE EN NEDERLANDSE GEREFORMEERDES}

In 'n kerkverband as genootskap-regspersoon het die meerdere vergaderings as bestuursorgane daarvan die bevoegdheid wat aan hul kragtens die statute van die regspersoon toegeken is. Mens 
kan dit oorspronklike bevoegdheid noem, omdat die bevoegdheid regstreeks deur die regspersoon verleen is sonder tussenkoms van die lede wat die genootskap vorm. Die sinode het dan oorspronklike, eerste-hands gesag.

In 'n kerkverband as verbondsooreenkoms van selfstandige, maar deur die ooreenkoms inter-afhanklike gemeentes, is die bevoegdheid van sinodes bepaal deur die stipulasies van daardie verbond en die opdragte van die gemeentes aan hul afgevaardigdes wat die sinode vorm, maar wat uiteindelik verantwoordelik bly aan hul opdraggewende gemeentes, wat mag en moet beoordeel of hul binne die grense van hul gesag en opdrag gehandel het. In dié opvatting het 'n sinode afgeleide, tweede-hands gesag. Hierdie uitdrukking moet nie opgevat word met die bedoeling om die waarde van die korrespondensie tussen gemeentes te onderskat of, erger nog, te ondermyn nie.

Volgens ' $n$ Duitse juris ${ }^{47}$ het die Franse Sinode van 1559 reeds die konfederatiewe karakter van die kerkverband verander in die rigting van ' $n$ bestuursorgaan ${ }^{48}$. Hy betoog dat hierdie opvatting deur die sinode van Emden van 1571 en daaropvolgendes in Nederland verwerp is. Die kerkrade wat die gesag oor die gemeentes het, het afgevaardigdes vir die meerdere vergaderings benoem om daar as hul verteenwoordigers te handel. Die sinodes het daarom geen oorspronklik gesag gehad nie, maar was amptelike instansies, „Behörden”, of organe van die eintlike gesagsdraers, d.i. die plaaslike gemeentes.

Daar is verskil tussen die Dordtse en Ned. Geref. Kerkordes.

Art. 20.1 KO NGK bepaal dat meerdere vergaderings, elkeen na sy eie aard, 'n kerklike gesag deur Christus aan hulle verleen, het. Hierdie stelling weerspieël die eerste opvatting dat ,kerkverband" as bestuursorgane optree.

Art 36 DKO het volgens sy bewoording net betrekking op die gesag van meerdere vergaderings, nie op dié van kerkraad oor die gemeente nie.

Die yslike verskil tussen die twee standpunte ${ }^{49}$ het in Nederland gedurende die Doleansie en in 1944-1946 na vore gekom.

Art 36 DKO beskou die ,kerkverband" as societas. Daarom het al vyf Nederlandse geregshowe, na aanvanklike aarseling, art 36 DKO nie as verhindering beskou vir die reg van 'n plaaslike gemeente om hom aan die correspondentia, as dit korrup geword het, te onttrek nie ${ }^{\text {so }}$. Hierdie regstoepassing deur die howe was die regstreekse aanleiding vir die GKN (sinodaal) om die DKO vaarwel te sê en hul regspersoon-genootskaplike opvatting van die kerkverband in 'n nuwe KO te formuleer. Ongelukkig het die NGK in SA daardie formulering, soos vermeld, oorgeneem en in hulle $\mathrm{KO}$ ingebou.

\section{DIE KRAG VAN 'N VENNOOTSKAPLIKE KERKVERBAND}

Met die eerste oogopslag wil dit voorkom of 'n vennootskaplike in plaas van 'n genootskaplike verband van gemeentes die eenheid van die kerk in die wêreld swak vertoon. Die teendeel is egter die geval. 
As die gelowiges milites Christi (soldate van Christus) is, leer die moderne leër- en verdedigingsorganisasie dat aan afsonderlike gevegseenhede groter selfstandigheid gegee word. Die troepe moet wyer verspreid wees en in kleiner eenhede hul taak uitvoer. Dit sou dwaas wees om in 'n oorlog die totale leërmag op een plek te plaas.

Sedert die Pinksterbedeling is dit ook met die kerk die geval. Die kerk is op baie plekke geïnstitueer. As die kerk in een stramme band van die sentraliserende wêreldbeweging geklem word, kan die kerk met een slag deur die vyand vir homself geannekseer word. Die hoofkwartier kan geinfiltreer word en al die plaaslike gemeentes verduister word.

Aan die ander kant leer die vergelyking met die militêre ontwikkeling dat die plaaslike selfstandigheid van die gemeentes hul verantwoordelikheid en verpligting vergroot om die samewerkingsverband met ander gemeentes te bewaar en sodoende die totale belang van die kerk van Christus op aarde te dien. Vennootskaplike verband is geen independentisme nie. Ons moet daarom enersyds die gestrengheid èn die soepelheid van die KO eerbiedig. In oorlogstyd en kerklike chaos kan dit egter ook nodig wees om in insidentele gevalle van die $\mathrm{KO}$ af te wyk juis om die trou van die vennootskaplike verbond te bewaar ${ }^{51}$.

In so ' $n$ vennootskaplike kerkverbond word niemand met kerkregtelike magsmiddels gedwing om teen sy gewete, die eis van God en die reg van die kerk, te handel nie: Hy kry tyd vir behandeling van sy beswaar. Die sinodokrasie is nie net 'n oorskatting en oorspanning van die kerkverband nie, maar 'n vermoording daarvan. Die Skrif spreek van kerkverband in sy wese as beoefening van die gemeenskap van die gelowiges deur Woord en Gees, wederkerig deur plaaslike gemeentes. Die Skrif laat die vorm van verbandsoefening aan die gelowiges oor, maar die roeping daartoe lê wel in die Skrif opgesluit. Die Belydenis leer in art 32 dat niks teen die insetting van Christus mag plaasvind nie. Dit is wel die geval in 'n genootskaplike kerkverband wat tot hiërargie lei. Die kerkgeskiedenis bewys dit ${ }^{52}$.

\section{DIE DESENTRALISERENDE BOODSKAP OP SOSIO-POLITIEKE GEBIED}

Hierdie anti-sentraliserende strekking van 'n vennootskaplike kerkverband bevat ook wysheid vir ander menslike gemeenskappe. In die staatkunde kan 'n te sterk sentrale gesag die lewe in plaaslike gemeenskappe vernietig. Die hart van die nasie klop in sy plaaslike gemeenskappe. Solank hul funksioneer, sal 'n vreemde oorheerser nooit die nasie kan vernietig nie ${ }^{53}$.

'n Staatsbestel met grondwetlike waarborge vir die munisipaliteite as primêre gesagsdraers vir alle plaaslike belange, waarin regionale en hoër gesag eers in aksie kom vir sover hul self nie kan klaar kom nie, is desentraliserend. Die daadwerklike deelneming van die burgers aan die uitoefening van die gesag, is van uitsonderlike, gemeenskapsvormende en politieke betekenis. Die 
plaaslike verbondenheid van die inwoners is die mees aktiverende middel vir die omsetting van medewerkingsimpulse in daadwerklike politieke aktiwiteit. Dit voldoen aan 'n menslike behoefte om in lokale bestuur te partisipeer. Die neiging tot sentralisasie van die kant van hoër gesag en gevolglike robotisme en burokrasie van sy amptenary dwing tot ' $n$ veronagsaming van die belange van die burgers. In ons eeu van idustrialisasie moet meer as ooit hieraan aandag geskenk word ${ }^{54}$.

Wat hier van goeie burgerskap gesê word, geld in nie mindere mate van die gelowiges in die plaaslike gemeentes nie ${ }^{55}$.

\section{DIE SENTRALISASIE IN DIE GENOOTSKAPSREGSPERSOON}

In 'n kerkverband as genootskapregspersoon kom sentralisasie van kerkbestuur in plaas van desentralisasie na vore. Die Roomse kerk is daarvan nie enigste voorbeeld nie. Daar word beweer dat in die reg van die NGK die kerkverband die eienaar van ' $n$ sinodale sentrum, die werkgewer van 'n groot personeel, 'n kontrakterende party teenoor die argitek en die boumeester van sy sinodale sentrum is; die kerkverband kan dagvaar of gedagvaar word. Dit is geen fiksies of abstraksies nie, maar die regswerklikheid so. Hieruit volg egter geensins dat dit ooreenkomstig gereformeerde kerkreg is nie.

As die „kerkverband" „kerk" is, kan die ,kerk” ook sy eie ampsdraers hê: sinodale predikante. Waar vind 'n mens dit in die klassieke gereformeerde tradisie? Om uit hierdie praktyk 'n beginsel af te lei, is gelyk aan die perd agter die wa te span.

Origens verdien dit vermelding dat nie net 'n regspersoon, maar ook ' $n$ vennootskap personeel in diens kan hê. Net soos 'n vennootskap van prokureurs klerke kan aanstel, kan 'n vennootskaplike kerkverband 'n kerklike buro instel en onderhou. So 'n kerkverband het feitlik 'n sterk blywende karakter solank die gemeenskaplike geloofsbelydenis die grondslag van al die gemeentes is ${ }^{57}$.

Die krag van die werklik gereformeerde kerkverband is in die geskiedenis aanwysbaar. Die Reformasie het 'n bres geskiet in die Roomse hiërargie. Die kerklike chaos was toe onvoorstelbaar. Art 9 DKO herinner nog daaraan deur groot versigtigheid voor te skryf ten opsigte van mispriesters en monnike wat predikante wil word. Die plaaslike gemeentes, vrygemaak uit die Roomse kerk, was dikwels so swak dat hul op eie kragte nie kon klaar kom nie. Arts 38 en 39 DKO sê dat die klassis moet help om inkomplete gemeentes voorlopig deur 'n genabuurde kerkraad te laat versorg.

Veral die klassisse illustreer hoeveel waarde 'n vennootskaplike kerkverband vir die plaaslike gemeentes gehad het. Toe was 'n landelike kerkgenootskap (vgl. Rome en Lutherane) by die gereformeerdes onbekend. Vir die praktiese gemeenteopbou in die naReformasietyd het klassisse lank die belangrikste meerdere vergaderings gebly. Die Hollandse kerk was 'n samestel van klassisse. Die Weselse artikels van 1568 het nie van sinodes nie, maar net van klassisse gepraat. Dordrecht 1574 gee 'n noukeurige verdeling van klassisse, maar noem nêrens provinsiale sinodes nie. Die Kerkorde van 1578 noem hul wel, maar omskryf net, soos Sinode 1581, 
die taak van die klassisse. Hul het tot kerkinstituering oorgegaan en kerklike ampte ingestel, gewoonlik deur middel van visitatore. As die ampte plaaslik nog nie ingestel was nie, was dit die klassisse wat afdwalende lidmate vermaan het, toesig op die benoeming van skoolmeesters uitgeoefen het en predikante in vakante gemeentes beroep het. Die gemeentes het die gesag van die klassisse aanvaar. Pas ten tye van die Remonstrantse twiste kom sporadies ernstig verset teen die klassisse voor ${ }^{88}$. Waarskynlik het die verset voortgekom toe in die provinsie in 1612 ' $\mathrm{KO}$ ingevoer is wat die owerheid van Holland in 1591 opgestel het. Daarin is die vrywillige vennootskaplike karakter van die kerkverband vernietig en van die kerk 'n staatsdepartement gemaak ${ }^{8 \theta}$.

\section{DIE GEREFORMEERDE KERK EN KERKVERBAND IS SUI JURIS}

Die gereformeerde kerkreg is eiesoortig. Dit bevat wel toepassing van algemene regsbeginsels, soos hiervoor betoog t.o.v. die societaskarakter van die kerkverband, t.o.v. las en volmag aan afgevaardigdes vir meerdere vergaderings, t.o.v. regspersoonlikheid van plaaslike gemeentes, ens. Die enigste grondslag daarvan bly egter stceds die waarheid van die Heilige Skrif.

\section{VOORBEELDE VAN DIE EIESOORTIGE KARAKTER VAN DIE GEREF. KERKREG T.O.V. WERELDLIKE REG}

1. Die gereformeerde kerkreg is selfs nie in die geval van die plaaslike gemeente kollegialisties nie. Dit blyk uit die bewoording van art $32 \mathrm{NGB}$. Die oorspronklike teks, wat die Dordtse Sinode in 1619 vasgestel het praat oor die vasstelling van ' $\mathrm{KO}$ nie soos die Afrikaanse vertaling dit weergee nie. Dit praat nie van 'n kollege, kerkraad, wat die gemeente verteenwoordig nie. Dit praat selfs nie oor regeerders van die kerk, soos die Afrikaanse teks dit weergee nie, maar van hulle ,die Regeerders der Kerk zijn". Dit is 'n onderwerpsin wat die nadruk op die tydelikheid van die ampte laat val ${ }^{80}$. 'n Kerkraad daarenteen, is soos die plaaslike gemeente blywend van aard, ondanks die wisseling van sy lede. Die ouderlingskap word vooropgestel en nie die lidmaatskap van die kerkraad of die kerkraad as kollege nie, d.w.s. die beginsel van presbiteriale kerkregering.

2. Dit is opvallend dat die NGB net op een plek melding maak van die "Raad der Kerk". Art 30 vermeld in die Afrikaanse teks dat die ouderlinge daar is „om saam met die herders as die Raad van die Kerk te wees". Die offisiële Franse teks van 1619 noem dit "comme le Senat de l'Eglise”, d.w.s. „soos die raad van die kerk". "Die Latynse vertaling is hiermee in ooreenstemming en lui "Senatum quasi Ecclesiae constitutant”, d.w.s. „asof dit 'n regeringsraad is". Die rede hiervoor lê in die feit dat die presbiteramp en nie die kerkraad as kollege nie, uitgangspunt vir die kerkregering vorm en omdat die persoonlike verantwoordelikheid van ampsdraers nie skuil mag gaan agter die kerkraad as kollege nie.

Vonk ${ }^{61}$ sê: "De kerkeraad is als het ware de senaat van de kerk.... De woorden als het ware vindt men in de eerste uitgave 
onzer belijdenis, die van de Bres 1561, nog niet. Men heeft ze later ingevoegd om toch vooral te voorkomen, dat de overheid zou denken, dat de predikanten, ouderlingen en diakenen met elkaar een tegenvroedschap wilden vormen. Daarom: als het ware. Zoals de overheid haar senaat had, zo had de kerk die ook, maar uitdrukkelijk schreef Calvijn, dat het werk van de senaat der kerk van geheel andere aard was dan dat van de overheidssenaat IV, 11. Ook de Bres had hier in art 30, voor alle zekerheid, al gesproken van geestelijke orde en van geestelijk bestraffen."

3. Die Afrikaanse teks van art 11 KO GKSA praat van „Die kerkraad wat die kerk verteenwoordig". Art 11 DKO is duideliker: „de Kerkeraad, als representerende de gemeente”. Hier kan geen misverstand wees nie, want gemeente is plaaslike kerk. Die kerkraad verteenwoordig nog direk, nog indirek 'n provinsiale of landelike kerk. Die woord gemeente, ekklesia, dui primêr op die vergadering van die gelowiges waaraan, as regsgevolg, regspersoonlikheid van die plaaslike gemeente verbind is ${ }^{62}$. Dit is opvallend omdat die DKO op baie ander plekke wel die uitdrukking, kerk' gebruik as dit om die plaaslike gemeente gaan. Moontlik word bedoel om die plig van die gesamenlike gemeentelidmate te benadruk. In art 11 DKO gaan dit om die onderhoud van die predikamp en die persoonlike plig van die lidmate hieromtrent. Dit sluit aan by die verklaring van die vierde gebod volgens die Heidelbergse Kategismus. In art 19 DKO waar dit om die onderhoud van teologiese studente gaan, word ook die woord ,gemeente" gebruik.

Art 29 DKO noem die kerkraad nie 'n kollege nie, maar 'n kerklike samekoms.

4. Die bevestigingsformulier van dienare van die Woord sê dat hul saam met die ouderlinge die goeie orde en tug moet uitoefen. Die bevestigingsformulier vir ouderlinge sê dat hul met die dienare „des Woords ' $n$ college of gezelschap uitmaken, zijnde als ${ }^{03}$ een raad der kerk, en vertonende de hele gemeente". Dit is nodig om dominokrasie teen te gaan ${ }^{64}$. Dit gaan hier nie om verteenwoordiging van die plaaslike gemeente as 'n regspersoon na buite nie, soos afgelei sou kon word uit die Afrikaanse teks nie, wat lui: "So vorm die bedienaars van die Woord en die ouderlinge saam ' $n$ liggaam of vergadering, om te dien as 'n Raad van die Kerk wat die hele gemeente verteenwoordig." Volgens die konteks gaan dit hier om handhawing van die kerklike tug in die gemeente.

5. Die handhawing van die tug in die kerk is nie 'n dissiplinêre maatreël wat op een lyn staan met handhawing van die orde binne enige, voluntary association' nie. Dit word uitgedruk in art 30 NGB, wat oor ,geestelike politie' ${ }^{\text {es }}$ en in toom hou van oortreders op geestelike wyse spreek. Art $71 \mathrm{KO}$ stel eweneens dat die Christelike straf geestelik is. Art $30 \mathrm{KO}$ beperk die bevoegdheid van sinodes tot kerklike sake.

Die wêreldlike howe wat hul die reg aanmatig om daardie sake te toets en in te gryp in die lewensfeer van die kerk, handel bo hul kragte omdat die geestelike sake nie van hierdie wêreld en alledaagse reg is nie. Die staat mag hierdie kerklike vryheid nie aantas nie. 
6. Die DKO is anti-formalisties. Die kerkreg kan nie asem haal in die sfeer van die wêreldlike reg nie ${ }^{68}$. Dit is die gevolg van die geestelike dimensie van die kerkreg, ongrypbaar vir beoordeling deur 'n wêreldlike hof ${ }^{67}$. Die DKO druk dit uit in art 86: „Die gemeente, klassis of sinode zullen naarstigheid doen om die DKO te onderhouden, totdat anders van de Generale of Nationale Synode verordend worde." In die Afrikaanse teks: "hulle moet hul daarop toelê om dit (die $\mathrm{KO}$ ) te onderhou, totdat" ens.

Hierdie woorde beteken dat skending van formele voorskrifte van die DKO nie noodsaaklik nietigheid van 'n besluit tot gevolg het nie. Dit is anders in geval van die slot van art $31 \mathrm{DKO}$, as 'n besluit in stryd is met die Woord van God.

\section{VAN DIE KERKORDE KAN AFGEWYS WORD OMDAT DIT GEEN WET IS NIE}

Omtrent die bewoording ,naarstigheid doen' kan opgemerk word dat dit net betrekking het op die inspanning en nie 'n waarborg vir die bereik van die beoogde resultaat inhou nie. Dit volg uit die oud-Nederlandse en Latynse woordgebruik in die regstaal ${ }^{88}$. Voetius laat hom in dieselfde $\sin$ uit ${ }^{69}$. Hy sê dat van die KO afgewyk mag word mits (1) dit 'n goeie doel dien, te wete die goeie orde in die kerk van Christus, art $1 \mathrm{KO}$; (2) as sodanig eerlik erken word en dit mag nie tot 'n nuwe wet word nie, d.w.s. hy verwerp presedentereg; (3) die redes aan die oordeel van 'n bevoegde kerklike vergadering onderwerp word. 'n Skriftuurlike voorbeeld kom voor waar Dawid van die toonbrode eet ten spyte van Lev. $24: 9$. Vgl Matth. $12: 3$.

Hierdie afwyking stel egter die eis van Lev, $15: 18$ nie ter syde nie. Daaruit volg drie reëls: (a) die nood en noodsaak moet aantoonbaar wees; (b) die afwyking moet so gering moontlik wees (die reinheid van Dawid se manne); (c) die erkenning van die afwyking dra 'n anti-farisese, anti-judaistiese karakter en verwerp dus wettisisme.

As hedendaagse voorbeeld kan genoem word ${ }^{70}$ waar 'n predikant wat op Saterdag dronk was, dieselfde aand voorlopig geskors word. So 'n skorsing wat art 79 DKO nie ken nie (wel art 79 KO GKSA) behoort so gou moontlik met medewerking van 'n genabuurde kerkraad beoordeel te word. Hierdie afwyking van art 79 DKO word geregverdig deur: (i) die publisiteit van 'n ergerlike sonde; (ii) die roeping en openlike bediening van die Woord wat in die teken van die triomf van die genade moet staan; (iii) die tydnood wat tydige raadpleging èn medewerking van die genabuurde kerkraad as tweede regter verhinder. So 'n voorlopige skorsing stel geen skuld vas nie. 'n Formalistiese nalewing van art 79 DKO sou ten koste van die gemeente kon geskied ${ }^{11}$.

Dieselfde beginsel geld vir die toepassing van voorskrifte van die KO omtrent beoefening van die kerkverband. Daardie KO is geen wet van Mede en Perse nie. Dit staan daarom in die algemeen aan die bevoegdheid van die kerklike vergaderings met uitsluiting van die burgerlike howe om te beoordeel of die KO juis toegepas is ${ }^{72}$. 


\section{VERMOENSREGTELIKE VRAE OOR DIE KERKVERBAND}

Die beantwoording van die vraag aan wie kerklike goedere behoort, is afhanklik van die organisasie van die kerkverband. Dit is in confesso dat plaaslike gemeentes eiendom besit en dat onroerend goed derhalwe in hul naam geregistreer is.

In die ongereformeerde opvatting dat die kerkverband as geestelike eenheid van meer gemeentes 'n regspersoon is - waarteen regtens weens die bestaande godsdiensvryheid geen beswaar bestaan nie - kan eiendom in die naam van die betrokke regspersoon geregistreer word.

Die eiendom van ' $n$ vennootskap behoort aan die vennote persoonlik. Nogtans is dit, solank die vennootskap bestaan, vermoë wat afgeskei is van die orige vermoë van die vennote ${ }^{73}$. In 'n handelsvennootskap kan 'n vennoot die eiendom van 'n goed inbring. sodat die vennote mede-eienaars word. So 'n inbring word vergoed deurdat die vennootskap as eenheid 'n skuldenaar word ten opsigte van die geldswaarde van die inbringende vennoot vir sy kapitaalinbring en hy bowendien 'n rente daarvoor uit die wins of 'n ekstra deel van die wins kry. Eenvoudiger en dikwels beter is om nie die eiendom self, maar net die genot of gebruik daarvan in te bring. Ekonomies kom dit neer op huur as daarvoor vergoed word. Regtens is dit egter geen huur nie.

Op dieselfde manier kan 'n plaaslike gemeente die gebruik van sy kerkgebou, al of nie teen vergoeding, afstaan vir 'n meerdere vergadering. Dit is nog huur, nog skenking, maar voldoening aan 'n verpligting wat uit die kerkverband voortvloei.

Dit kan ook gebeur dat 'n kerkverband vir bepaalde doeleindes tot fondsvorming moet oorgaan, byvoorbeeld voldoening aan emeritaatsverpligtinge. Die kas van 'n vennootskaplike kerkverband is dan vermoë wat afgeskei is van die orige vermoë van die plaaslike gemeentes, hoewel hul sakeregtelik eienare bly. Solank die kerkverband bestaan, het hul geen reg om hul aandeel in daardie vermuë op te eis nie, net soos in geval van enige andere vennootskap.

\section{DIE GKGN (VRYGEMAAK) EN VERMOENSREGTELIKE VRAE}

Die GKN (Vrygemaak) het by die tegniese hersiening van hul KO in 1978 daarop soos volg op die beginsel in die DKO voortgebou: Art 52 ,De kerken worden voor het burgerlijk recht ten aanzien van vermogensrechtelijke aangelegenheden, die zij in classicaal, particulier-synodaal of generaal-synodaal verband gemeenschappelijk hebben, vertegenwoordigd door de respectieve classicale, particulier-synodale of generaal-synodale vergaderingen, of door deputaten die door deze vergaderingen worden benoemd, geïnstrueerd en ontslagen en die in al hun handelingen aan hun instructie gebonden zijn.' Hier word duidelik uitgedruk dat die kerkverband 'n gemeenskap is, nie 'n regspersoon nie.

Deur hierdie hersiening is art $84 \mathrm{KO}$ wat in 1933 ingevoeg was, afgeskaf. Daardie bepaling was eintlik 'n ,Fremdkörper' in die gereformeerde kerkreg, sonder dat dit aan die kerkverband sy vennootskaplike karakter ontneem het ${ }^{74}$. Volgens sy bewoordinge het hier- 
die bepaling net betrekking op vermoënsregtelike eenhede ten aansien van stoflike aangeleenthede. Die kerkverband in sy geestelike eenheid het daardeur nie 'n regspersoon geword nie. In die toetssaak voor die Hoge Raad was uitsluitend die 1933-teks van art 84 $\mathrm{KO}$ in die geding en is die regspersoonlikheid aangeneem.

\section{DIE NGKSA EN VERMOENSREG}

Indien die kerkverband as regspersoon opgevat word, sou so 'n bepaling oorbodig gewees het. Tereg ontbreek so 'n voorskrif in die KO van die NGK. Art 55 (teks 1970) lui so: „Elke kerkvergadering sal die nodige voorsiening maak vir die sorgvuldige beheer van die stoflike aangeleenthede van die Kerk en jaarliks verslag doen van sy rentmeesterskap aan die gemeente, ring, sinode of Algemene Sinode, soos die geval mag wees." As mens dit lees in verband met art 36: „Die samestellende kerke of sinodes behou ten volle seggenskap oor hul ciendomme...." en saam lees met andere bepalings waaruit die pretensie volg dat die kerkverbande eie regspersoonlikheid besit, is dit heeltemal duidelik dat die NGK 'n genootskapregspersoon is, wat uit regspersone van beperktere omvang opgebou is.

\section{VERMOENSREGTELIKE BY SKEURING}

Die Nederlandse art 84 KO van 1933 was eintlik oorbodig. Privaatregtelik is daar geen verhindering dat lede van 'n vennootskap 'n stigting in die lewe roep, wat sakeregtelik as eienaar in die aktekantoor vir onroerend goed geregistreer kan word nie. Dié weg is o.a. gevolg deur die Gereformeerde Gemeenten in Nederland en die Gereformeerde Kerken (vrygemaak) vir hul teologiese hogeskoolgeboue. Of dit altyd ' $n$ billike oplossing gee in geval van 'n wettige afskeiding of reformasie dan wel in geval van 'n sondige skeuring, laat ek hier rus.

Die ergste wat 'n plaaslike gemeente en 'n kerkverband kan oorkom is 'n onwettige skeuring. Die geskiedenis hier en oorsee gee daarvan ongelukkig voorbeelde ${ }^{75}$. Die vermoënsregtelike gevolge daarvan kan nie altyd opgelos word deur die party wat die goedere beheer of wat beweer dat hy die wettige voortsetting van gemeente of kerkverband is of dat hy as alleen-eienaar van al die goedere wat deur gesamentlike bydraes betaal is, erken moet word nie ${ }^{76}$.

'n Hiërargiese landelike kerkorganisasie en ook 'n sogenaamde veiligstelling van goedere in 'n kerkelike stigting, kan die gelowiges in die verleiding bring om die Skriftuurlike opdrag om eers die Koninkryk van God en sy geregtigheid te soek, te veronagsaam. Dit belemmer 'n Skriftuurlike reformasie soos die jare 1816, 1834, 1886 en 1944 in die Nederlandse kerkgeskiedenis bewys. Hoe min ouer en beswaarde predikante het in 1944 die moed gehad om hul teenoor die sinodehiërargie uit te spreek uit vrees dat hul hul emeritaatsregte sal verbeur? 


\section{DIE KERKBEGRIP VAN DIE DRIE AFRIKAANSE KERKE VERSKIL}

Uit wat hiervoor gestel is, blyk dat die bewering dat die drie Afrikaanse kerke ampelik ooreenstem dat die kerkverband wel 'n korporasie, maar geen genootskap is nie verwarrend en ongegrond is. Hierdie stelling ${ }^{77}$ bots met die $\mathbf{N G b}$., die gereformeerde kerkreg van Voet en met die DKO.

Ek hoop dat ek met hierdie uiteensetting 'n bydrae gelewer het vir 'n vrugbare gesprek tussen teoloë uit drie Afrikaanse Kerke sowel as in die verhoudingsprobleme wat die NGK en sy sogenaamde dogterkerke ondervind.

Pinetown, Junie 1980.

\section{VOETNOTE}

1 G. Voet, Politica Ecclesiastica, Pars tertia, Tractatus III (waarna hierna ook verwys word), Caput II par 2 III.

2 Caput II par 2 I

3 Die vertaling van Latynse uitdrukkings is ooreenkomstig die woordeboeke van H. H. Mallinckrodt, Utrecht/Antwerpen 1972 en van F. Postma, HAUM Kaapstad/Pretoria 1972.

4 Institute 3.26 .1$.

5 Glosse op Inst 3.26.1: haec societas fraternitas inducit.

Digeste $17.263 \mathrm{pr} .$. . cum societas just quodammodo 1 (in sekere sin) fraternitas 2 in se habeat.

Glosse 1: societas non est proprié (in eintlike sin) fraternitas seu communio, sed per societatem inducitur communio justa lucri et damni... jus quodammodo fraternitas in se continet, non est tamen vera fraternitas....

Glosse 2: Fraternites nomine etiam communitas significatur... Fratrum quoque nomine et communitas apparet et aequalitas dignitatis.... sacra res est unitas et quaedam fraternitas animorum ('n sekere broederskap van hart en gees).

G. Noodt, Opera omnia, Leiden 1760 ad D 17.2 le die nadruk op die gelykheid soos van broeders: ... societas.... est contractus juris gentium bonae fidei, constans consensu de lucro et damno communis rei aut operae, inter socios communicando... quodammodo in se habere jus fraternitatis: id est quoddam jus aequalitatis, nam hanc indigitat fraternitas... Nec alia causa est, cur nobis invicem fratrum nomen impertiamus, nisi quia pares esse nos credimus.... Sacra res est, et quaedam fraternitas conjunctio bonorum.

6 Digesta $17.2 \mathrm{pr}$.

7 Inleidinge tot de Hollandsche Rechts-geleerdheid 3.21.1.

8 Inleidinge t.a.p. 321.3.

9 D. Fourie, Die Kerkbode 20 Februarie 1980 sien dit oor die hoof. Hy bestry die opvatting van B. Spoelstra, Handleiding by die KO van die GKSA, Potchefstroom 1966 bl 16, dat die gereformeerde kerkverband 
as vennootskap beskou kan word $H y$ beweer dat 'n vennootskap 'n ooreenkoms tussen partye is wat wins beoog. ' $n$ Kerkverband sou daarom nie 'n vennootskap kon wees nie.

10 Jolles, De kenmerken van de overeenkomst van maatschap, juridies proefskrif Leiden 1932 bl 82.

11 Hoge Raad der Nederlanden 7 Desember 1955, Nederlandse Jurisprudentie 1956 no 163, Beslissingen in Belastingzaken 1956/41, Periodiek Woordenboek van administratieve en gerechtelijke beslissingen 16462 .

12 Thymon Boey, Woorden-tolk of verklaring der voornaamste onduitsche en andere woorden in de hedendaagsche en aloude rechtspleginge voorkomende, 's-Gravenhage 1773 bl 744.

13 M. J Koenen, Nederlands woordenboek.

14 Institute 1.2 8: Responsa prudentium sunt sententiae et opiniones eorum, quibus permissum erat de Jure respondere.... J Voet, Commentarius ad pandectas 1.2 .8 en 9 oor die jurisconsultes.... cum enim antiquitus de jure responderent ....

15 Consultatien, Advysen en Advertissementen gegeven ende geschreven by verscheyden treffelijcke Rechts-geleerden in Holland, Rotterdam 16451666 , ses dele

J. van der Linden, Verhandeling over de Judicieele Practijcq of Form van Procedeeren, Amsterdam 1794 (tweede druk 1829) eerste deel bl 6-7, deel oor die Hollandse KO van 1791 met betrekking tot albej die Hollandse synodes mee: ,In elke Sijnode heeft men een Praeses, een Assessor, en een Scriba. Door het zelve worden benoemd Correspondenten, om met de andere bijzondere Sijnoden gemeenschap te onderhouden, en dezelve bij te woonen, schoon egter daar in alleenlijk eene adviseerende, en geene besluitende stem hebbende'....

16 In die Skriflig, Maart 1979 bl 30-31.

17 D. Fourie, proefskrif 1973 bl 172 beweer dat die kerkraad as die orgaan van die gemeente in 'n maatskapsverhouding optree met verantwoording aan die gemeente en die reèls van kontrakreg is van toepassing. Hierdie stelling ag ek geheel en al foutief.

18 Vgl Christian Meurer, Die Juristischen Personen nach Deutschem Reichsrecht, Stuttgart, Verlag von Ferdinand Denke 1901 bl 5-9.

19 E J. J. van der Heijden, De ontwikkeling van de Naamlooze Vennootschap in Nederland vóor de Modificatie, Amsterdam 1908, Hoofstuk II Karakter en ontstaan van de Oost-Indische Compagnie bl 39-83.

20 S J. Fockema Andreae, De Nederlandse Staat onder de Republiek, Amsterdam 1961

21 D. Fourie tipeer in Die Kerkbode van 27 Februarie 1980 Rutgers en Lohman as reaksionêre Doleansie-kerkregtelikes. Ongekontroleerd praat hy, ook in sy proefskrif 1973 , net $M$. Bouwman en D. Nauta na.

22 D. Fourie stel op bl 277 van sy proefskrif dat ,gemeenteskeurings regtens 'n rewolusionere daad is'. Op bl 274 stel hy die skrywer van hierdie artikel voor ,as 'n juris uit die kring van die „vrygemaaktes" in Nederland wat gemeenteskeurings as normaal beskou'. Die Vrymaking van 1944-1946 was dus rewolusie en ek is 'n rebel. Op my klag dat hy in gebreke bly om die bewyse daarvoor te vermeld uit die offisiële dokumente, het hy aan my toegese dat as ek kan bewys dat die teendeel die geval is, hy sy stelling onvoorwaardelik sal intrek. Hierdie wonderlike omkering van bewyslas is in stryd met die reël negativa non sunt probanda. 
In die Kerkbode van 5 Maart 1980 stel D. Fourie egter: Die onverbiddelike, liefdelose benadering van die sinodes in Nederland b.m.t. die Vrygemaktes in 19.44 is ' $n$ goeie voorbceld (dat sinodes liefdeloos, reglemen. terend en formalisties kan wees en sodoende die selfstandigheid van die gemeente in die gedrang kan bring). Die gevolgtrekking lyk vir my dat D. Fourie 'n voorstander van die sinodokratiese kerkreg bly, maar die toepassing daarvan soms verwerp.

23 D. Fourie, proefskrif bl 68 beweer daarom ten onregte dat die Nederlandse wet die kerkverband altyd tot 'n regspersoon verklaar. Dit sou trouens in stryd wees met die meeste hofbeslissings oor die gereformeerde kerkverband.

24 Advokaat J. Meulink het as parlementslid my suggestie hieromtrent in die Nederlandse Juristenblad opgevolg: Kyk Lucerna, Gereformeerd Interfacultair Tijlschrift 1958 bl $43-44$.

Volgens S. J. Fockema Andreae, Rechtsgeleerd Handwoordenboek, Groningen 1951 beteken, reglemente' dikwels wette vir publiekregtelike liggame; ,statuten' grondreëls en bepalings van bepaalde regspersone; ,statuut' o.a. reëling van belangrike aard, byvoorbeeld die ,statuut' van die Internasionale Geregshof en die ,Academisch Statuut' wat reëls vir universiteitsonderwys beskryf.

25 Code 4.22 Plus valere quod agitur quam quod simulate concipitur.

26 In die Skriflig, Maart 1979 bl 28.

27 D. Fourie, Die Kerkbode 20 Februarie 1980, is verward in sy terminilogie as hy beweer dat 'n genootskap identies met ' $n$ societas is. Hy beroep hom op J, F. Uys, Die genootskapsooreenkoms, juridies proefskrif Leiden 1961. Hierdie skrywer handel egter oor die oprigtingsooreenkoms van 'n genootskap as 'n regspersoon sonder winsoogmerk. Die Sanlam en Ou Mutual is voorbeelde daarvan. Hulle is onderlinge versekeringsgenootskappe wat sonder winsoogmerk vir aandeelhouers werk, net in die geldelike en ander belang van hul polishouers as lede daarvan.

Fourie gebruik in Die Kerkbode van 27 Februarie 1980 die woord ,korporasie' as aanduiding van 'n regspersoon. Hierdie woord is uit die Engelse regstaal afkomstig en onbekend in die Romeinse reg. Vgl Fockema Andreae t.a.p. bl 79: ,Corporatie (Freng corporation. Veelal eenvoudig= rechtspersoon'.

Petit Larousse illustré 1974 (vertaal deur my): Corporation (engelse woord in Frankryk ingevoer in die 18e eeu) Vereniging van persone wat dieselfde beroep uitoefen en wat voor 1971 in Frankryk aan strenge reglementering onderwerp was.

The Concise Oxford Dictionary 1964 bl 273-274: United body of persons esp. one authorized as an individual; artificial person created by charter, prescription, or act of legislature, comprising many persons .... or one ....

Van Leeuwen 4.1312 sou volgens Fourie, proefskrif 1943 bl 48 en Die Kerkbode 27 Februarie 1980, oor ,collegien als Kerken' spreek. In sy voorwoord van sy Rooms-Hollandse Regt verwys hy hul wat Latyn verstaan, na sy werk Censura Forensis. In die 1741 edisie daarvan 1.4.9.6. Se Van Leeuwen dat 'n stilswyende verband kan bestaan ten behoewe van hul wat (3) net soos minderjariges onder owerheidstoesig staan...., Item ad acclesia, (4) et Ecclesiastica collegia, ut sunt Nosocomia, Xenodochia, aliaque pauperum et miserabilium Collegia'... Van Leeuwen stel hier langs mekaar plaaslike gemeentes en diakonale inrigtings, soos 
hospitale, gashuise en andere kollegies vir armes en behoeftiges. Vgl ook Censura Forensis 2.1.6.2,3. Die diakens het in regte opgetree sonder om hulself as 'n kollegie aan te dui: Kyk In die Skriflig Maart 1979 bl 35-36 voetnoot 3 . Dit alels het niks te doen met die vraag of 'n kerkverband regspersoon is al dan nie

Ook Huber het die term ,korporasie' nie gebruik nie, maar volgens Fourie proefskrif 1973 bl 48: universitates; eweneens net met betrekking tot plaaslike gemeentes.

28 D. Fourie verwys na $M$. Bouwman wat dit beweer, in plaas van hierdie hoorse-getuienis self te toets uit die eie geskrifte van Voetius.

29 Caput II par 1, II.

30 ' $n$ Kudde is wel 'n liggaam, maar geen regspersoon nie. Kyk In die Skriflig Maart 1977 bl 31 . Omtrent coetus en congregatio sien K. Schilder, Verzamelde werken, De kerk Deel I, Goes 1960 bl 155-160. Dié benamings kom in art 27 NGB voor. Volgens hom is 'n coetus 'n samekoms, wat beteken dat mense uit eie krag na mekaar gaan. Congregatio is 'n groep van lewende wesens wat bymekaar gebring is, deur 'n dwingende krag in ' $n$ kudde, 'n troep; dus passief.

31 Caput II par 2 pr.

32 Kyk voetnoot 24.

33 Caput II par 2 I.

34 Die uitdrukking, instituta ecclesia het geen betrekking op 'n sinodale of klassikale ,kerk' nie.

35 Waarskynlik word bedoel dat die gemeente deur deel te neem aan korrespondensie met ander gemeentes niks van sy wese prys gee nie.

36 Collaterales is bloedverwante wat, soos erfgename, almal in dieselfde posisie staan.

37 Caput II par 2 III.

38 Caput II par 3 I.

$39 \mathrm{Vgl}$ die gemeente van Genève ten tye van Calvyn wat nie in 'n kerkverband geleef he $\iota$ nie; voorts die onvolkome kerkverband van die Kaapse kerk in die Nederlandse tyd. Vgl ook Voet Caput II par 5 III: Ecclesia pariochalem esse Ecclesiam veram essentialiter et integraliter, asbque illa correspondentia ('n plaaslike gemeente is wesenlik en volkome 'n ware kerk ook sonder daardie kerkverband.

41 Waarskynlik bedoel Voet hier dat, hoewel die correspondentia vas en blywend bedoel is, die sinodale gesag ad hoc is: kyk PE IV bl 167 hierna.

42 D. Fourie mak hiervan dat 'n sinode 'n conventus ecclesiarum is. Dit se Voet nie en dit is ook onrealisties. Was daar ooit ' $n$ klassis of ring gehou waarin al die gemeentelede of al die ouderlinge van die betrokke gemeen. tes saamgekom het? Art 79 DKO ken wel die geval van 'n gekombineerde vergadering van twee kerkrade.

43 Caput III par 3 III, 2.

44 So stel D. Fourie dit hiervoor onder 1.4.

45 F. E. O'Brien Geldenhuys Die regsposisie van kerkraad, ring en sinode, soos toegepas in die gefedereerde Ned. Ger. Kerke in Suid-Afrika, Stellenbosch 1951 bl 152 (aan wie die sitaat van Voet ontleen is).

46 D. Fourie vermeld in Die Kerkbode van 27 Februarie net die slot van hierdie antwoord, wat hy uit sy verband ruk, as beweerde bewys dat Voet die kerkverband as 'n regspersoon beskou. Vgl ock Voet $I .1$ bl 131. Ecclesia notat hic primo particulares quesque topicas in civitatibus aut 
vicis, deinde ex illis combinates seu confoederatione, correspondentia aut arctiori quadam uniome et necessitude collectas et quasi concorporales (Bouwman se: concorpores is 'n drukfout) quas nationales, provinciales, districtuales appellant. (Kerk dui hier in die eerste plek die afsonderlike plaaslike gemeentes in die state of dorpe aan, daarna die gekombineerde gemeentes uit hulle, of wat bymekaar gebring is deur bondgenootskap, korrespondensie en verwantskap in 'n sekere eenheid asof (quasi) hul tot een liggaam of bond verenig is, welke nasionale, provinsiale of regionale kerke (meervoud) genoem word).

47 Hermann Edler von Hoffmann, Das Kirchenverfassungsrecht der nieder. ländischen Reformierten bis zum Beginne d erDordrechter Nationalsymode von 1618/19, Leipzig 1902 bl 153.

48 Kyk ook D. Deddens, De eerste Synode der Franse Gereformeerde Kerken te Parijs 1559, Lucerna I 1958 99-120.

49 D Fourie sien dit volgens sy brief hieroor 1.5 punt 3 nie raak nie.

50 Voetius Caput II par 3, 1 en Caput V par 2, VI.

51 H. J. Schilder, onder skuilnaam Miles Victor, Gesprek met Juvenalis. Motto: Ik geloof het verband-der-kerk en het kerkverband, De Reformatie 29e jrg nr 43, 31 Julie 1954 bl 346.

52 H. J. Schilder, De vrijmaking als bewaring van het kerkverband, De Reformatie 31e jrg no 3, 15 Oktober 1955.

53 C. F. Menger, professor in staatsreg, Universiteit van Munster, Deutsche Verfassungsgeschichte der Neuzeit, Uni-Taschenbucher 930, 1979 bl 194, 197 deel mee dat in 1945 die geallieerde militere regerings die gehele bestuur van Duitsland oorgeneem het. Hul het hul bestuursinstellings van bo na onder opgebou, maar het die bestuur oor die munisipaliteite nooit oorgeneem nie. By die wederopbou het die bestaande plaaslike Duitse bestuur die omgekeerde beginsel toegepas. Die toestand in 1945 in Duitsland was vergelykbaar met die aan die einde van die 30-jarige oorlog in 1648. Die volk was fisies en psigies geheel en al uitgeput en daarenbowe vol skaamte en verbystering oo rdie oorlogsmisdade wat die nasionaal-sosialiste in sy naam gepleeg het Hoewel die plaaslike bestuur in sy bevoegdheid baie gekortwiek was, is dit 'n wonder dat die Duitse plaaslike owerhede die onmiddellik dreigende chaos in 'n verwoeste land met miljoene vlugtelinge afgewend het.

54 Edzard Schmidt-Jortzig, professor in die ,Kommunalwissenschaften' aan die Universiteit van Munster, rede 5 November 1979, Schriftenreihe des Niedersächsischen Städteverbandes Heft 7: Verfassungsmässige und soziologische Legitimation gemeindlicher Selbstverwaltung heute'.

Dieselfde skrywer wys in sy ,Einrichtungsgarantien der Verfassung, Dogmatischer Gehalt und Sicherungskraft einer umstrittenen Figur' Göttingen 1979 op die bestaan van 'n regsvoorskrif in die Bondsrepubliek Duitsland wat die outonomie van plaaslike en regionale besture grondwetlik beskerm. Die besondere konstitusionele geregshof moet wetgewing in stryd daarmee, ook van die sentrale parlement, onverbindend verklaar.

55 In die Duitse en Nederlandse taal word dieselfde woord vir munisipaliteit en plaaslike kerk gebruik, naamlik ,Gemeinde' en gemeente. Die een is die burgerlike, die ander die kerklike gemeente.

56 D, Fourie voeg hieraan toe: ,Die kerkverband as 'n voortdurende verband van gemeentes staan soos 'n koei voor jou, soos die Nederlanders sou se.' Ek vra: is 'n koei 'n regspersoon of 'n verhandelbare saak? Bestaan daar 
so 'n algemene Nederlandse segswyse of is dit net spraakgebruik van hiërarge of sinodokrate?

57 Vgl Heidelbergse Kategismus, vraag en antwoord 54, art 27 NGB.

58 Ontleen aan A. Th. van Deursen, Bavianen en Slijkgeuzen, Kerk en kerkvolk ten tijde van Maurits en Oldebarnevelt, Van Gorkym \& Co Assen 1974 bl $5-7$.

59 C. Hooijer, Oude Kerkenordeningen der Nederlandsche Hervormde Gemeenten (1563-1638) .... Zaltbommel 1865 bl 339-350.

60 Lepusculus Vallensis, De Nederlandsche Geloofsbelijdenis in het licht der H. Schrift, Uitgave van de Stichting voor Gereformeerde Publicaties, Zwolle 1951 bl 150.

61 C. Vonk, De voorzeide leer, deel IIIb, De Nederlandse Geloofsbelijdenis, Barendrecht 1956 bl 151.

62 D. Fourie se gebruik van die uitdrukking van 'n kerkraad as permanente kollegie en van meerdere vergadering as tydelike kollegie verklaar hom teen sy wil as 'n kollegialis. Die kerklike papiere gebruik daardie term glad nie in die geval van sinodes en klassisse nie.

63 In die Nederlandse taal kan ,als' sowel ,as sodanig' beteken as ,zoals', soos, asof... Die Afrikaanse taal laat geen moontlikheid vir dié moontlike misverstand nie.

$64 \mathrm{Vgl} \mathrm{J}$. Kamphuis, ,Door dit middel' in Verkenningen III Opstellen over Kerk en Kerkrecht, Goes 1966 bl 191-200. Hy betoog dat as Calvyn oor die kerkraad skryf, hy veral dink aan waarborge teen eenhoofdige kerkregering in sy reaksie teen Rome. In verband met die regs sekerheid in die handhawing van die tug verwys art 30 NGB na die kerkraad (nie omdat dit 'n kollegie is nie), maar omdat dit meerhoofdig is, 'n groep presbiters.

65 Lepusculus Vallensis t.a.p. bl 144, 146: Politie beteken hier: grondwet, bestuursvoorschriften.

66 L. Roeleveld, Beginselen van kerkelijke rechtspraak, In die Skriflig, Maart 1972 bl 41-51.

67 Hierdie stelling behoort in 'n afsonderlike studie aandag te kry.

68 J. R. Wiskerke, ,De Reformatie 40e jrg nr 22 van 6 Maart 1965 bl 177-178 wys op die taak van die Advocaat-Generaal volgens die Groot-Placaetboek van 1502: ,Hy sal oock alle neerstigheyt aanwenden, om ... de Placaeten ... wel te doen onderhouden'. Merula, Manier van Procederen, Leiden 1741 bl 286 vermeld dat die eed van die fiskaals moet inhou dat hul ,met alle vlyt en neerstigheid hun taak verrrichten'. Die advokate-eed het volgens Merula ta.p. 298 dieselfde strekking. Vgl Glosse by Codex 3.114.1 se in clientis sui causam nullam operam mullmque studium intermissuros, dat hul in die saak van hul klient geen enkel moeite en ywer sal nalaat nie.

69 Ontleen aan J. R. Wiskerke, De Reformatie 13 Maart 1965 bl 184-185.

70 J. R. Wiskerke, De Reformatie 20 Maart 1965 bl 192-193.

71 J. R. Wiskerke, De Reformatie 27 Maart 1965 bl 199-202.

72 Die formalistiese toepassing van $\mathrm{KO}$, Bepalinge en Reglemente van die NGK, byvoorbeeld dat betrokkenes hul in beswaarskrifte en prosedure daaraan streng moet hou (Bepaling 172 NGK Natal 1967) word dus afgewys. Dit kan vir ongeletterde gelowiges die kerklike weg afsny.

Om uit SA wetgewing van 1843 en 1961 en uit hofbeslissings van niegereformeerde regters af te lei wat die karakter van die gereformeerde 
kerkverband is, is ' $n$ petitio principii d.i. om as bewys aan te voer wat juis bewys moet word.

73 D. G. van der Keessel, Theses Selectae 779, Leiden 1800 bl 261: ...ex juris ratione de re communi socius invito socio disponere nequeat...: na regte kan 'n vennoot nie teen die wil van sy mede-vennoot oor gemeenskapsgoed beskik nie.

74 Stelling V proefskrif L. Roeleveld, Leiden 1955: ,Art 84 KO van de GKN heeft, door slechts te spreken van de vermogensrechtelijke eenheden en niet van eenheden zonder meer, de uitsluitende strekking gezamenlijke eigendommen van kerken tot haar zelfstandige onderdelen te verklaren'... .

D Fourie vra na die bekende weg, want uitvoerig kommentaar op art 84 sinds die teks van 1933 het ek gegee in my geskrif ,Gereformeerde Kerken in het Privaatrecht, Zeist 1958 bl $57-69$, wat hy in sy proefskrif 1973 vermeld. Net soos Nauta in sy Verklaring het Fourie dié kommentaar, waar hy nou om vra, geignoreer.

75 D. Fourie vra my opinie oor die saak J. J. Venter, J. J. Joubert, A. L. de Wet en anderen ca den Kerkeraad der Gereformeerde Kerk te Bethulie 1879 OVS 4. Hierdie saak handel oor die vraag of die plaaslike gemeente 'n regspersoon was, wat tereg bevestigend beantwoord is. Daar was twee groepe in die gemeente wat onderling geloofsverskille gehad het. Een groep het toe ' $n$ eis ingestel tot ontbinding van die regspersoon en verdeling van sy goedere. Die vraag is nie aan die hof gestel welke van die groepe die oorspronklike gemeente is of verteenwoordig is nie. Ook is nie beweer dat daar twee gemeentes in plaas van een sou wees nie. Die hof het die gemeente nie as ontbonde beskou nie en die eis afgewys Die ratio decidendi munt nie uit deur helderheid nie. Ek kry die indruk dat sowel die regsverteenwoordigers as die hoofregter verward was omtrent die feite en die beredenering van die regsvrae. Die gesag van hierdie presedent is vir my daarom baie twyfelagtig. Dit bjed geen aanknopingspunt tot oplossing van geskille as gevolg van skeuring in 'n ven. nootskaplike kerkverband nie. Kyk vir die opvatting van D. Fourie oor hierdie saak sy proefskrif 1973 bl 55, 278.

76 Sien my artikel, Afskeiding, skeuring en roeping tot eenwording', In die Skriflig???

77 D. Fourie, Die Kerkbode 5 Maart 1980. 